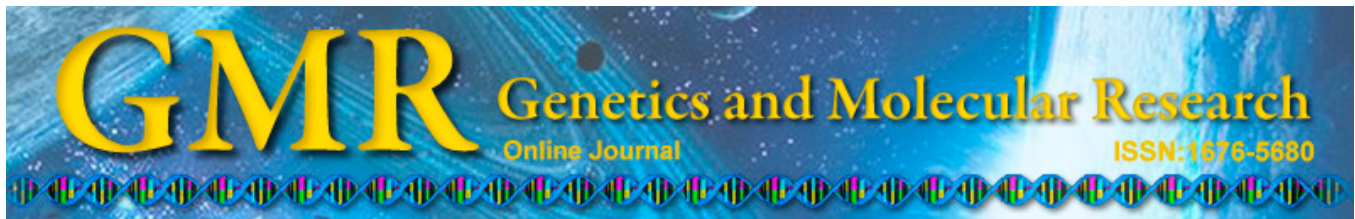

\title{
Epistasis and inheritance of plant habit and fruit quality traits in ornamental pepper (Capsicum annuum L.)
}

\author{
R.M.C. Santos ${ }^{1}$, E.R. do Rêgo ${ }^{2}$, A. Borém ${ }^{3}$, M.F. Nascimento ${ }^{1}$, \\ N.F.F. Nascimento ${ }^{1}$, F.L. Finger ${ }^{3}$ and M.M. Rêgo ${ }^{2}$ \\ ${ }^{1}$ Programa de Pós-Graduação em Genética e Melhoramento, \\ Universidade Federal de Viçosa, Viçosa, MG, Brasil \\ ${ }^{2}$ Laboratório de Biotecnologia Vegetal, Centro de Ciências Agrárias, \\ Universidade Federal da Paraíba, Areia, PB, Brasil \\ ${ }^{3}$ Departamento de Fitotecnia, Centro de Ciências Agrárias, \\ Universidade Federal de Viçosa, Viçosa, MG, Brasil \\ Corresponding author: R.M.C. Santos \\ E-mail: rusthoncortez@hotmail.com / rusthon.santos@ufv.br
}

Genet. Mol. Res. 13 (4): 8876-8887 (2014)

Received November 8, 2013

Accepted April 2, 2014

Published October 31, 2014

DOI http://dx.doi.org/10.4238/2014.October.31.3

\begin{abstract}
Two accessions of ornamental pepper Capsicum annuum L., differing in most of the characters studied, were crossed, resulting in the F1 generation, and the F2 generation was obtained through selffertilization of the F1 generation. The backcross generations RC1 and RC2 were obtained through crossing between F1 and the parents P1 and $\mathrm{P} 2$, respectively. Morpho-agronomic characterization was performed based on the 19 quantitative descriptors of Capsicum. The data obtained were subjected to generation analysis, in which the means and additive variance $\left(\sigma_{a}^{2}\right)$, variance due to dominance deviation $\left(\sigma_{d}^{2}\right)$, phenotypic variance $\left(\sigma_{f}^{2}\right)$, genetic variance $\left(\sigma_{g}^{2}\right)$ and environmental variance ( $\sigma_{m}^{2}$ ) were calculated. For the full model, we estimated the mean effects of all possible homozygotes, additives, dominants, and epistatics: additive-additive, additive-dominant, and dominant-dominant. For the
\end{abstract}


additive-dominant model, we estimated the additive effects, dominant effects and mean effects of possible homozygotes. The character fruit dry matter had the lowest value for broad sense heritability (0.42), and the highest values were found for fresh matter and fruit weight, 0.91 and 0.92 , respectively. The lowest value for narrow sense heritability was for the minor fruit diameter character (0.33), and the highest values were found for seed yield per fruit and fresh matter, 0.87 and 0.84 , respectively. The additive-dominant model explained only the variation found in plant height, canopy width, stem length, corolla diameter, leaf width, and pedicel length, but in the other characters, the epistatic effects showed significant values.

Key words: Full model; Additive-dominant model; Additive effects; Mean analysis; Analysis of variance

\section{INTRODUCTION}

Plants of the Capsicum genus have a long history of use in culinary preparations and, more recently, as ornamental plants. In recent years, with the creation of breeding programs for plants of the Capsicum genus, there has been a demand to increase diversity within the types of pepper, both in the ones used in cooking and the ornamental ones. Within this genus, there is an abundance of genetic diversity for an array of characters such as plant growing habits as well as for characters related to size and color of fruit and leaves, which makes it possible to meet the demands for the creation of new types (Stommel and Bosland, 2006).

The breeding programs for Capsicum can be developed through the selection of plants from preexisting populations as well as hybridization. The development of a new variety that is attractive to the consumer as to high yield of fruit, colorful and erect fruit, and harmonic canopy is one of the main goals in any breeding program. The first step to a successful genetic breeding program is the selection of the parents. However, this is also the most expensive and time consuming step of any breeding program (Geleta and Labuschagne, 2004). Genetic diversity is considered one of the criteria used in the selection of parents in the production of a hybrid. Geleta and Labuschagne (2004) showed that parents more closely related genetically present low heterosis, while crosses between parents of diverging classes tend to show higher heterosis for fruit and plant size characters.

The knowledge of nature and of the magnitude of genetic effects is of the utmost importance in the process of selection and predicting the behavior of the hybrid and segregating generations (Cruz and Regazzi, 2001). Thus, the aim of this study was to estimate the genetic parameters and genetic effects involved in the inheritance of plant size and fruit characters in a segregating generation of ornamental pepper.

\section{MATERIAL AND METHODS}

Two accessions (76 and 77.3) of ornamental pepper Capsicum annuum L. belonging to BGH-UFPB (Active Germplasm Bank of plants of Universidade Federal da Paraíba) differing in most of the characters studied, were crossed, resulting in the F1 generation, and the F2 generation was obtained through self-fertilization of the F1 generation. The backcross 
generations $\mathrm{RC} 1$ and $\mathrm{RC} 2$ were obtained through crossing between $\mathrm{F} 1$ and the parents $\mathrm{P} 1$ and $\mathrm{P} 2$, respectively. These parents show contrasting characters, namely plant size and color of the leaves, flowers and immature and mature fruits. Plants from accession $76(\mathrm{P} 1)$ have a smaller size and larger leaves and fruits than do the ones from accession $77.3(\mathrm{P} 2)$, producing green foliage, white flowers, green immature fruits, and orange mature fruit. Plants from accession 77.3 are larger in size and have smaller leaves and fruits when compared to the plants from subsample 76; they also have dark purple leaves and flowers, and their immature fruits are also purple while mature ones are red. The crosses were carried out in a greenhouse using standard practices of emasculation (Rêgo et al., 2012).

The experiments with all the generations were conducted in a greenhouse. The characterization was performed at Laboratório de Biotecnologia Vegetal of UFPB, in Areia, Paraíba, Brazil. The seeds were sown in Styrofoam (polystyrene) trays of 128 cells filled with commercial substrate, and when seedlings displayed at least 6 leaves, they were transplanted to $700-\mathrm{mL}$ pots containing commercial substrate. The flower traits were evaluated starting at the appearance of the first flower in each plant, and plant size and fruit characters were evaluated starting at the appearance of the first mature fruit. Each plant was characterized individually according to its flowering and fruiting.

Morpho-agronomic characterization was based on the 19 quantitative descriptors of Capsicum proposed by IPGRI (1995), using 10 plants of each parent and of the F1 generation, and 180, 90 and 90 plants of the $\mathrm{F} 2, \mathrm{RC} 1$ and $\mathrm{RC} 2$ generations, respectively.

The fruit traits evaluated were pedicel length $(\mathrm{cm})$, fruit length $(\mathrm{cm})$, major fruit diameter $(\mathrm{cm})$, minor fruit diameter $(\mathrm{cm})$, fruit weight $(\mathrm{g})$; pericarp thickness $(\mathrm{cm})$, seed yield per fruit, and dry matter content (\%).

The plant traits evaluated were plant height $(\mathrm{cm})$, canopy width $(\mathrm{cm})$, stem length $(\mathrm{cm})$, stem diameter $(\mathrm{cm})$, leaf length $(\mathrm{cm})$, petiole length $(\mathrm{cm})$, and leaf width $(\mathrm{cm})$, while the flower traits evaluated were corolla width and petal width.

The data obtained were subjected to generation analysis, where we calculated the means and additive variance $\left(\sigma_{a}^{2}\right)$, variance due to dominance deviation $\left(\sigma_{d}^{2}\right)$, phenotypic variance $\left(\sigma_{f}^{2}\right)$, genetic variance $\left(\sigma_{g}^{2}\right)$, and environmental variance $\left(\sigma_{m}^{2}\right)$ as shown below.

Phenotypic variance in $\mathrm{F}_{2}$ :

$$
\hat{\sigma}_{f(F 2)}^{2}=\hat{\sigma}_{F 2}^{2}
$$

Mean variance:

$$
\hat{\sigma}_{m(F 2)}^{2}=\frac{2 \hat{\sigma}_{F 1}^{2}+\hat{\sigma}_{P 1}^{2}+\hat{\sigma}_{P 2}^{2}}{4}, \hat{\sigma}_{m(R C 1)}^{2}=\frac{\hat{\sigma}_{F 1}^{2}+\hat{\sigma}_{P 1}^{2}}{2} \text { e } \hat{\sigma}_{m(R C 2)}^{2}=\frac{\hat{\sigma}_{F 1}^{2}+\hat{\sigma}_{P 2}^{2}}{2}
$$

Genetic variance in F2:

$$
\hat{\sigma}_{g(F 2)}^{2}=\hat{\sigma}_{f(F 2)}^{2}-\hat{\sigma}_{m(F 2)}^{2}
$$


Additive variance:

$$
\hat{\sigma}_{a}^{2}=2 \hat{\sigma}_{g(F 2)}^{2}-\left[\hat{\sigma}_{g(R C 1)}^{2}+\hat{\sigma}_{g(R C 2)}^{2}\right]
$$

where:

$$
\hat{\sigma}_{g(R C 1)}^{2}=\hat{\sigma}_{f(R C 1)}^{2}-\hat{\sigma}_{m(R C 1)}^{2} \mathrm{e} \hat{\sigma}_{g(R C 2)}^{2}=\hat{\sigma}_{f(R C 2)}^{2}-\hat{\sigma}_{m(R C 2)}^{2}
$$

Variance due to dominance deviation:

$$
\hat{\sigma}_{d}^{2}=\hat{\sigma}_{g(F 2)}^{2}-\hat{\sigma}_{a}^{2}
$$

Heritability estimates were calculated in the broad $\left(h_{a}^{2}\right)$ and narrow $\left(h_{r}^{2}\right)$ sense, and the average degree of dominance $\left(k_{m}\right)$ was also determined.

Broad-sense heritability:

$$
h_{a}^{2}=\frac{\hat{\sigma}_{g(F 2)}^{2}}{\hat{\sigma}_{f(F 2)}^{2}}
$$

Narrow-sense heritability:

$$
h_{r}^{2}=\frac{\hat{\sigma}_{a}^{2}}{\hat{\sigma}_{f(F 2)}^{2}}
$$

Average degree of dominance:

$$
k_{m}=\frac{2 \overline{F_{1}}-\left(\overline{P_{1}}+\bar{P}_{2}\right)}{\bar{P}_{1}-\bar{P}_{2}}
$$

For the full model, we estimated the mean effects of all possible homozygotes (m), additives (a), dominants (d), and epistatics: additive-additive (aa), additive-dominant (ad) and dominant-dominant (dd). For the additive-dominant model, we estimated the additive effects (a), dominant effects (d) and mean effects (m).

Generation mean analysis for the full model is given below:

$$
\hat{m}=\frac{1}{2} P_{1}+\frac{1}{2} P_{2}+4 \overline{F_{2}}-2 \overline{R C_{1}}-2 \overline{R C_{2}}
$$




$$
\begin{gathered}
\hat{a}=\frac{1}{2} P_{1}-\frac{1}{2} P_{2} \\
\hat{d}=-\frac{3}{2} P_{1}-\frac{3}{2} P_{2}-\overline{F_{1}}-8 \overline{F_{2}}+6 \overline{R C_{1}}+6 \overline{R C_{2}} \\
a \hat{a}=-4 \overline{F_{2}}+2 \overline{R C_{1}}+2 \overline{R C_{2}} \\
a \hat{d}=-P_{1}+P_{2}+2 \overline{R C_{1}}-2 \overline{R C_{2}} \\
d \hat{d}=P_{1}+P_{2}+2 \overline{F_{1}}+4 \overline{F_{2}}-4 \overline{R C_{1}}-4 \overline{R C_{2}}
\end{gathered}
$$

All effects from both models were subjected to a $t$-test at the $5 \%$ level of significance. All analyses were performed using the Genes statistical software (Cruz, 2006).

\section{RESULTS AND DISCUSSION}

There are many published researches that associate some known genes to specific characters in the genus Capsicum (Zewdie and Bosland, 2000; Rêgo et al., 2009; Bnejdi et al., 2009). In some of these studies, the inheritance of quantitative characters related to plant morphology was not described in great detail. However, it has been observed that these characters may not have monofactorial inheritance as suggested but are in many cases determined by more than one gene. Plant characters related to plant size or fruiting usually exhibit quantitative inheritances that show an additional variability in relation to other characters (Wang and Bosland, 2006).

\section{Means and heritabilities}

For the characters related to plant size, the parent 77.3 (P2) showed higher means than did the parent $76(\mathrm{P} 1)$, and the F1 generation showed intermediate values for all traits, except for plant height and canopy width (Table 1), demonstrating that for these characters, the predominant type of allelic interaction would be subdominant.

Regarding the stem length, stem diameter, leaf length, pedicel length, and leaf width traits, the predominant allelic interaction was additive, since the F1 generation displayed intermediate means in relation to the parents (Table 1).

Corolla width in the F1 generation was smaller than in the parents, indicating that overdominance was the predominant allelic interaction, which was confirmed in the analysis of the F2 generation, which showed transgressive phenotypes to the maximum value of the parents, thus demonstrating that selection can be done to increase this character.

For the petal width trait, we found an intermediate pattern of the F1 generation in relation to its parents, indicating that the predominant gene interaction was additive (Table 1).

In the fruit traits studied, the ones that showed overdominance as the predominant al- 
lelic interaction were minor fruit diameter, fruit weight, pericarp thickness, and seed yield per fruit. All of them also showed maximum transgressive values, demonstrating the occurrence of F2 generation genotypes with higher means compared to the parents. In fruit length, major fruit diameter, dry matter percentage, and pedicel length traits, we observed a predominant additive allelic interaction (Table 1 ).

\begin{tabular}{|c|c|c|c|c|c|c|}
\hline Generation & Arithmetic mean & Standard deviation & Arithmetic mean & Standard deviation & Arithmetic mean & Standard deviation \\
\hline & \multicolumn{2}{|c|}{ Canopy width } & \multicolumn{2}{|c|}{ Leaf width } & \multicolumn{2}{|c|}{ Fruit weight } \\
\hline P1 & 52.4 & 2.79 & $\overline{2.5}$ & 0.2 & 17.0 & 1.73 \\
\hline P2 & 22.0 & 2.64 & 2.66 & 0.28 & 45.3 & 2.88 \\
\hline $\mathrm{F} 1$ & 19.8 & 1.84 & 2.07 & 0.24 & 22.4 & 8.17 \\
\hline $\mathrm{F} 2$ & 27.2 & 5.73 & 2.17 & 0.37 & 32.3 & 19.73 \\
\hline $\mathrm{RC} 1$ & 31.8 & 5.73 & 2.10 & 0.25 & 22.1 & 13.96 \\
\hline \multirow[t]{2}{*}{$\mathrm{RC} 2$} & \multirow{2}{*}{\multicolumn{2}{|c|}{ Plat height }} & \multirow{2}{*}{\multicolumn{2}{|c|}{ Corolla width }} & 26.3 & 15.55 \\
\hline & & & & & \multicolumn{2}{|c|}{ Pedicel length } \\
\hline P1 & $\overline{64.6}$ & 2.08 & 1.70 & 0.09 & 1.00 & 0.31 \\
\hline P2 & 30.3 & 1.52 & 1.60 & 0.01 & 1.44 & 0.08 \\
\hline F1 & 19.3 & 1.49 & 1.45 & 0.10 & 1.88 & 0.26 \\
\hline $\mathrm{F} 2$ & 27.1 & 5.08 & 1.50 & 0.21 & 2.07 & 0.44 \\
\hline $\mathrm{RC} 1$ & 34.3 & 2.25 & 1.46 & 0.23 & 1.56 & 0.35 \\
\hline \multirow{2}{*}{$\mathrm{RC} 2$} & 23.7 & 3.87 & 1.44 & 0.12 & 1.92 & 0.38 \\
\hline & \multicolumn{2}{|c|}{ Stem length } & \multicolumn{2}{|c|}{ Petal width } & \multicolumn{2}{|c|}{ Pericarp thickness } \\
\hline P1 & $\overline{16.0}$ & 0.90 & $\overline{0.47}$ & 0.038 & 0.016 & 0.007 \\
\hline P2 & 10.6 & 1.15 & 0.26 & 0.021 & 0.016 & 0.007 \\
\hline F1 & 12.3 & 0.94 & 0.45 & 0.023 & 0.049 & 0.031 \\
\hline $\mathrm{F} 2$ & 12.7 & 2.25 & 0.45 & 0.055 & 0.048 & 0.033 \\
\hline $\mathrm{RC} 1$ & 14.3 & 1.38 & 0.40 & 0.045 & 0.028 & 0.015 \\
\hline \multirow[t]{2}{*}{$\mathrm{RC} 2$} & 13.2 & 2.10 & 0.43 & 0.051 & 0.087 & 0.035 \\
\hline & \multicolumn{2}{|c|}{ Stem diameter } & \multicolumn{2}{|c|}{ Fruit length } & \multicolumn{2}{|c|}{ Seed yield per fruit } \\
\hline P1 & 0.45 & 0.03 & $\overline{2.2}$ & 0.16 & 17.0 & 1.73 \\
\hline P2 & 0.58 & 0.03 & 0.55 & 0.056 & 13.3 & 2.88 \\
\hline $\mathrm{F} 1$ & 0.52 & 0.06 & 1.6 & 0.28 & 22.4 & 8.17 \\
\hline F2 & 0.79 & 0.11 & 1.79 & 0.55 & 32.3 & 19.73 \\
\hline $\mathrm{RC} 1$ & 0.52 & 0.07 & 1.95 & 0.45 & 22.1 & 13.96 \\
\hline \multirow[t]{2}{*}{$\mathrm{RC} 2$} & \multirow{2}{*}{\multicolumn{2}{|c|}{0.56 Leaf length }} & 1.21 & 0.45 & 26.3 & 15.55 \\
\hline & & & \multicolumn{2}{|c|}{ Major fruit diameter } & \multicolumn{2}{|c|}{ Fresh matter } \\
\hline P1 & 9.99 & 0.20 & 1.00 & 0.10 & 0.18 & 0.029 \\
\hline P2 & 6.16 & 0.28 & 0.49 & 0.03 & 0.06 & 0.021 \\
\hline $\mathrm{F} 1$ & 6.33 & 0.68 & 0.82 & 0.11 & 0.29 & 0.137 \\
\hline $\mathrm{F} 2$ & 7.12 & 0.99 & 1.01 & 0.24 & 0.61 & 0.335 \\
\hline $\mathrm{RC} 1$ & 6.98 & 0.71 & 1.00 & 0.19 & 0.28 & 0.253 \\
\hline \multirow{2}{*}{$\mathrm{RC} 2$} & 9.19 & 1.06 & 0.61 & 0.19 & 0.62 & 0.254 \\
\hline & Petio & length & Minor $\mathrm{fr}$ & it diameter & Dry & natter \\
\hline P1 & 2.84 & 0.13 & $\overline{0.72}$ & 0.025 & $\overline{0.016}$ & 0.007 \\
\hline P2 & 1.60 & 0.1 & 0.37 & 0.047 & 0.016 & 0.007 \\
\hline $\mathrm{F} 1$ & 1.80 & 0.46 & 0.42 & 0.079 & 0.049 & 0.031 \\
\hline $\mathrm{F} 2$ & 2.35 & 0.53 & 0.44 & 0.099 & 0.048 & 0.033 \\
\hline $\mathrm{RC} 1$ & 2.20 & 0.46 & 0.44 & 0.068 & 0.028 & 0.015 \\
\hline $\mathrm{RC} 2$ & 2.76 & 0.46 & 0.42 & 0.10 & 0.087 & 0.035 \\
\hline & & & Dry mat & er content & & \\
\hline & & Arithmetic mean & & & Standard deviation & \\
\hline P1 & & 0.09 & & & 0.023 & \\
\hline P2 & & 0.16 & & & 0.045 & \\
\hline $\mathrm{F} 1$ & & 0.13 & & & 0.041 & \\
\hline $\mathrm{F} 2$ & & 0.11 & & & 0.073 & \\
\hline $\mathrm{RC} 1$ & & 0.14 & & & 0.060 & \\
\hline $\mathrm{RC} 2$ & & 0.15 & & & 0.056 & \\
\hline
\end{tabular}


Similar results were found by Rêgo et al. (2011), who identified a predominant additive interaction for fruit length and major fruit diameter characters working with Capsicum baccatum.

Fruit dry matter had the lowest value for broad sense heritability (0.42) (Table 2), indicating that this trait is highly influenced by the environment. Narrow sense heritability for this character was also low (0.39) showing that there was a low correlation between the phenotypic and genotypic values, and as a result, the phenotypic value is not a reliable measurement for the genotypic value. Therefore, selecting for this character in early generations may not be efficient.

Table 2. Heritability estimates in the broad and narrow sense for plant size, flower and fruit in segregating population of ornamental pepper (Capsicum annuиm) obtained through crossing between 76 and 77.3 accessions.

\begin{tabular}{lcc}
\hline Characters & $h^{2}{ }_{a}$ & $h_{r}^{2}$ \\
\hline Canopy width & 0.83 & 0.56 \\
Plant height & 0.89 & 0.71 \\
Stem length & 0.80 & 0.74 \\
Stem diameter & 0.78 & 0.58 \\
Leaf length & 0.72 & 0.33 \\
Petiole length & 0.59 & 0.51 \\
Leaf width & 0.56 \\
Corolla width & 0.82 & 0.51 \\
Petal width & 0.75 \\
Fruit length & 0.84 \\
Major fruit diameter & 0.84 & 0.44 \\
Minor fruit diameter & 0.61 \\
Fruit weight & 0.92 & 0.38 \\
Pedicel length & 0.80 & 0.66 \\
Pericarp thickness & 0.86 & 0.75 \\
Seed yield & 0.90 & 0.33 \\
Fresh matter & 0.91 & 0.57 \\
Dry matter & 0.42 & 0.62 \\
Dry matter content & 0.71 & 0.66 \\
\hline
\end{tabular}

$\mathrm{h}^{2}=$ broad sense heritability, calculated according to Allard (1960) methodology; $h^{2}$ narrow sense heritability, obtained from the formula proposed by Mather (1949) and Warner (1952).

The characters that showed the highest values for broad sense heritability were fresh matter and fruit weight, with values of 0.91 and 0.92 , respectively, and their narrow sense heritability values were 0.87 and 0.57 , respectively. Therefore, the phenotypic values for these traits had a high correlation with the genotypic values. Moreira et al. (2010), working with $C$. annuиm lines, found similar results with genotypic determination coefficient values of 89.45 for fruit weight, 85.94 for fruit length and 85.94 for fruit diameter.

The fruit characters pedicel length, fruit length and major fruit diameter had broad sense heritability values higher than 0.8 and narrow sense heritability values higher than 0.6. The values obtained for minor fruit diameter were lower for both broad and narrow sense heritability, i.e., 0.61 and 0.33 , respectively. The relatively low heritability values for this trait could be explained by the low divergence in the parents selected.

There were transgressive phenotypes in the F2 generation for the maximum value in pedicel length, fruit length, major and minor fruit diameter, indicating the possibility of developing advanced lines with larger fruits compared to their parents, which is of great interest for the breeding of ornamental pepper plants.

The three leaf traits studied showed values higher than 0.5 for broad sense heritability 
and values of 0.330 .51 and 0.51 for leaf length, petiole length and leaf width, respectively, for narrow sense heritability. All characteristics displayed transgressive phenotypes for the maximum and minimum values in the F2 generation, enabling the development of new lines with larger or smaller leaves and, consequently, the selection of plants with smaller leaves for ornamental purposes.

For plant size characters, the highest value observed in broad sense heritability was 0.89 for plant height, whereas for narrow sense heritability, the highest value observed was 0.74 , for stem length. Other traits, such as canopy width, stem length and stem diameter, exhibited broad sense heritability values higher than 0.7 and narrow sense heritability values higher than 0.5. In the F2 generation, transgressive phenotypes for the minimum value of the parents in all characters were observed, except for stem diameter.

The selection of plants of smaller size is one of the main objectives in the breeding of ornamental pepper, as well as the selection of plants with larger stem diameter, which is important to prevent the tipping of plants.

Bento (2011), working with C. baccatum, found broad sense and narrow sense heritability values of 0.43 and 0.25 , respectively, for plant height, and for canopy width the author found equal broad sense and narrow sense heritability values of 0.16 , demonstrating very different results from the ones obtained in the present study.

The transgressive segregation observed in all characters, for the maximum values, the minimum values or for both, indicates that both parents (accessions 76 and 77.3) contribute alleles to either increase or decrease these traits (Zewdie and Bosland, 2000).

In all characters, except for leaf length and corolla width, the additive variance was higher than the variance due to dominance deviation, showing that most of the genetic variance was additive (Table 2). Ahmed et al. (1999), demonstrated that additive genetic variance was higher in magnitude when compared to dominance deviation variance for fruit length and diameter, pericarp thickness, seed yield per fruit, and fruit weight, which can ease selection by simplifying the strategies used in the process.

\section{Generation analysis}

The additive-dominant model was adequate to explain the genetic parameters for plant height, canopy width, stem length, corolla width and leaf width, with $\mathrm{R}^{2}$ values higher than $70 \%$. In all these traits, the additive effects as well as the dominance effects were significant in the $t$-test at $1 \%$ probability. This model was not adequate to explain the genetic parameters for the other plant size characters.

Martins Filho et al. (2002) found similar results in their study, where the additivedominant model was adequate to explain the variance found in canopy width and plant height in Capsicum.

The additive-dominant model was not enough to explain any fruit traits, except for pedicel length, indicating that epistatic interactions are important for these characteristics (Tables 3 and 4). Juhász et al. (2009) studied agronomic characters in pepper and found significant epistatic effects in the genetic control of those traits.

In all traits studied, except dry matter content, significant mean effects were observed (Tables 3 and 4).

Using the full model for stem diameter and leaf width characters, it was observed that all genetic effects were significant in the $t$-test at $1 \%$ probability. For petiole length, just the 
R.M.C. Santos et al.

8884

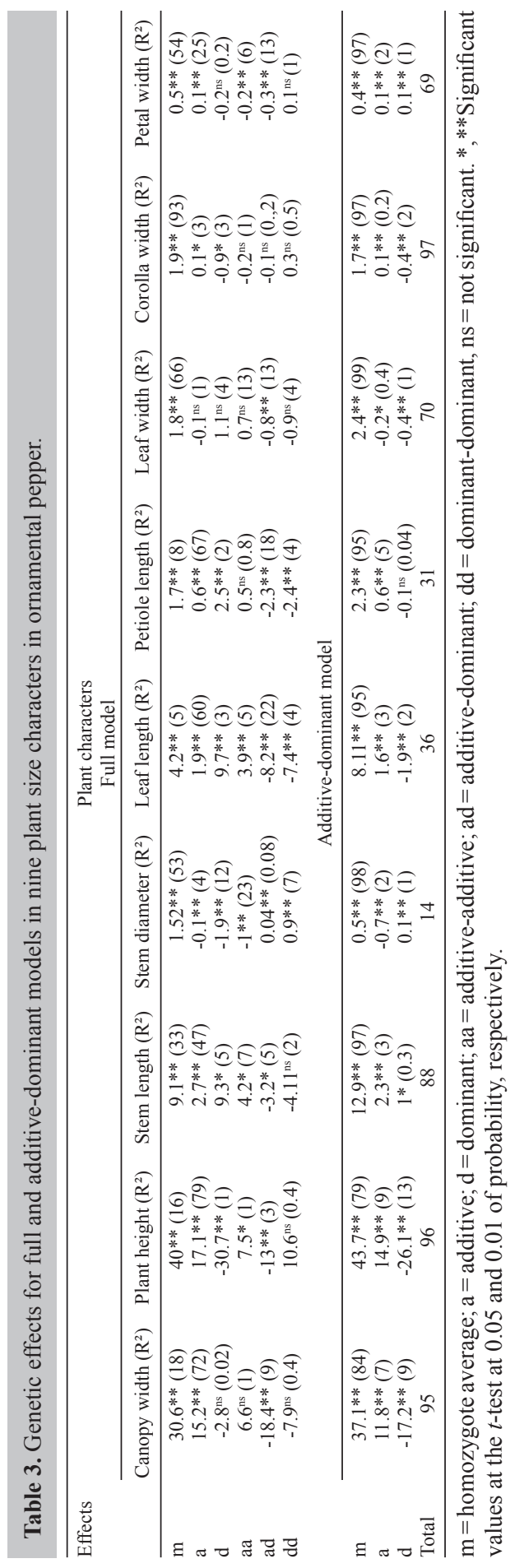




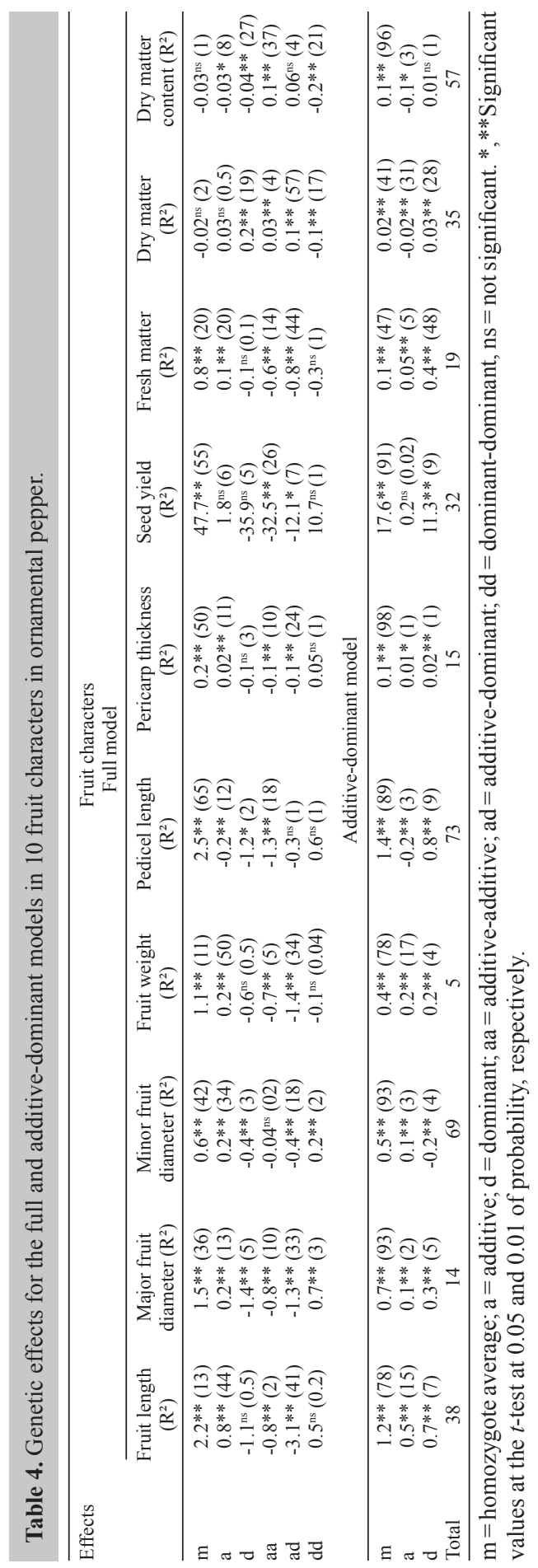


additive $\mathrm{x}$ additive interaction was not significant by the same test.

Petal width did not show any significant dominance effects and dominance-dominance interaction parameters. The selection process would be more effective, since the genetic effect for this trait was additive. Leaf size is a size plant character of great importance in the ornamental pepper trade since the leaves influence the canopy harmony.

When the additive effect is significant, the backcross generation means are biased to the recurring parent, implying that repeated backcrossing and selection could increase or decrease the desired character, according to the recurrent genotype used (Zewdie and Bosland, 2000).

All genetic effects were significant for major fruit diameter with dominance effect and additive-dominant interaction standing out. Fruit length and fruit weight traits showed a predominant additive effect and no significant dominance effect values as well as dominantdominant interaction values. Riva (2002) also noted that the full model was the most adequate to explain the fruit length and fruit diameter traits in C. annuum; however, they found that for fruit weight, the dominance effects were the most important, diverging from the results found in this research.

The seed yield per fruit and pericarp thickness both showed significance only in the aa and ad interaction effects. This behavior can be explained by the fact that these two characters are very closely related and are probably controlled by the same genes. Results obtained by Lippert et al. (1966) and Rêgo et al. (2009) showed similarity for these characters and indicated that variance was controlled by genes acting in additive and non-additive ways (dominance and epistasis).

As for fruit dry matter and fruit dry matter content, the mean effect was not significant in the $t$-test at $5 \%$ probability, and the additive effects were also not significant.

In minor fruit diameter, all genetic effects were significant, except for aa interaction. Lippert et al. (1965) showed that variance in the qualitative attributes of pepper was controlled by genes with non-additive action. On the other hand, Zambrano et al. (2005) showed that additive effects were higher than non-additive ones for this specific character in pepper. Rêgo et al. (2009) also obtained similar results for this character in C. baccatum.

A very efficient way of decreasing plant height, canopy width, leaf length and width, pedicel length and pericarp thickness, while increasing stem diameter and corolla width, could be achieved through repeated backcrossing and selection of desired recombinants from segregating populations, aimed at increasing the frequency of favorable alleles in the population for these traits.

According to Mather and Jinks (1977), a positive estimate of aa epistatic effect suggests that the gene pair is in an associated form and that only one of the parents contributes to increasing this character. This behavior pattern was observed in all fruit traits, except for dry matter content. It was also observed in stem diameter, corolla width and petal width. For all other characters, positive aa epistatic effects were observed, indicating that the genes were in dispersed form (Zewdie and Bosland, 2000).

\section{CONCLUSIONS}

There are predominantly over dominance and additive allelic interactions for plant size, which is of great importance for ornamental pepper breeding.

The high levels of heritability found in this work indicated the viability of using selec- 
tion in segregating generations and obtain considerable gains.

The additive dominant model explained only the variation found in plant height, canopy width, stem length, corolla diameter, leaf width, and pedicel length, but in the other characters the epistatic effects showed significant values.

\section{REFERENCES}

Ahmed N, Tanki MI and Jabeen N (1999). Heterosis and combining ability studies in hot pepper (Capsicum annuum L.). Appl. Biol. Res. 1: 11-14.

Allard RW (1960). Principles of Plant Breeding. John Wiley, New York.

Bento SC (2011). Melhoramento de Capsicum baccatum var. pendulum: Herança de Caracteres Agronômicos e Resistência ao Pepper Yellow Mosaic Virus. Doctoral thesis. Universidade Estadual do Norte Fluminense Darcy Ribeiro, Campos dos Goytacazes, 159.

Bnejdi F, Saadoun M, Allagui MB and El Gazzah M (2009). Epistasis and heritability of resistance to Phytophthora nicotianae in pepper (Capsicum annuum L). Euphytica 167: 39-42.

Cruz CD (2006). Programa Genes Versão Windows. Aplicativo Computacional em Genética e Estatística. Universidade Federal de Viçosa, Viçosa.

Cruz CD and Regazzi AJ (2001). Modelos Biométricos Aplicados ao Melhoramento Genético. 2nd edn. Universidade Federal de Viçosa, Viçosa.

Geleta LF and Labuschagne MT (2004). Hybrid performance for yield and other characteristics in peppers (Capsicum annuum L.). J. Agric. Sci. 142: 411-419.

IPGRI - International Plant Genetic Resources Institute (1995). Descriptors for Capsicum. IBPGRI, Rome.

Juhász ACP, Rodrigues R, Sudré CP and Pereira MG (2009). Detecção de ação gênica epistática no controle genético de características agronômicas em pimentão. Magistra 3: 203-210.

Lippert LF, Bergh BO and Smith PG (1965). Gene list for pepper. J. Hered. 56: 30-34.

Lippert LF, Smith PG and Bergh BO (1966). Cytogenetics of the vegetable crops. Garden pepper, Capsicum. Bot. Rev. 32: $24-55$.

Martins Filho S, Gravina GA and Sediyama CS (2002). Controle Genética da Resistência da Soja à Raça 4 de Cercospora sojina. Pesq. Agropec. Bras. 37: 1727-1733.

Mather K (1949). Biometrical Genetics. Methuen and Co., London.

Mather K and Jinks JL (1977). Introduction to Biometrical Genetics. Cornell University Press, Ithaca.

Moreira SO, Rodrigues R, Araújo ML, Riva-Souza EM, et al. (2010). Desempenho agronômico de linhas endogâmicas e combinadas de Capsicum annum L. em sistema orgânico sob cultivo protegido. Cienc. Agrotec. 4: 886-891.

Rêgo ER, Rêgo MM, Finger FL and Cruz CD (2009). A diallel study of yield components and fruit quality in chilli pepper (Capsicum baccatum). Euphytica 168: 275-287.

Rêgo ER, Rêgo MM, Cruz CD and Finger FL (2011). Phenotypic diversity, correlation and importance of variables for fruit quality and yield traits in Brazilian peppers (Capsicum baccatum). Genet. Resour. Crop Evol. 58: 909-917.

Rêgo ER, Nascimento MF, Nascimento NFF and Santos RMC (2012). Testing methods for producing self-pollinated fruits in ornamental peppers. Hort. Bras. 30: 708-711.

Riva EM (2002). Análise de Gerações para Reação à Mancha Bacteriana e Outros Caracteres Agronômicos em Capsicumannuит L. Master's thesis. Universidade Estadual do Norte Fluminense Darcy Ribeiro - UENF, Campos dos Goytacazes, 91.

Stommel JR and Bosland PW (2006). Ornamental Pepper, Capsicum annuиm. In: Flower Breeding and Genetics: Issues, Challenges and Opportunities for the 21st Century (Anderson NO, ed.). Springer, Dordrecht, 561-599.

Wang D and Bosland PW (2006). The genes of Capsicum. Hort-Science 41: 1169-1187.

Warner JN (1952). A method for estimating heritability. Agron. J. 44: 427-443.

Zambrano GM, González JRAD, Meraz MR and Loera AR (2005). Efectos genéticos y heterosis em la vida de anequel del Chile Serrano. Rev. Fitot. Mex. 28: 327-332.

Zewdie Y and Bosland P (2000). Capsaicinoid inheritance in an interspecific hybridization of Capsicum annuum and $C$. chinense. J. Am. Soc. Hortic. Sci. 125: 448-453. 